ARCHIWUM FILOZOFII PRAWA

I FILOZOFII SPOŁECZNEJ

$2020 / 2$

Paweł Jabłoński', Przemysław Kaczmarek ${ }^{2}$

Uniwersytet Wrocławski

\title{
O grze interpretatora z tekstem prawnym i czynnikami pozatekstowymi w derywacyjnej koncepcji wykładni prawa ${ }^{3}$
}

Zauważyć należy, iż tekst, któremu nie przypisuje się określonej interpretacji, jest przedmiotem zainteresowania jedynie kaligrafów czy drukarzy. Napis nie jest znakiem, dopóki nie przypisuje się mu jakiegoś sensu.

Zygmunt Ziembiński

Znaczenie jest w istocie grą pomiędzy interpretatorem a szeroko rozumianym tekstem ${ }^{5}$.

Maciej Zieliński, Marek Zirk-Sadowski

\section{Uwagi wprowadzające}

Celem artykułu jest przyjrzenie się derywacyjnej koncepcji wykładni prawa z punktu widzenia przyjętej przez nas struktury granic władzy prawniczej ${ }^{6}$. Niniejszy tekst jest kontynuacją przedsięwzięcia podjętego przez nas w innym miejscu, gdzie wyszczególniony układ granic był odnoszony do teorii socjologicznych i socjologiczno-prawnych ${ }^{7}$. Stosunkowo wąskie ramy, jakie łączą się z formą artykułu przesądzają o konieczności wprowadzenia dwóch ograniczeń. Po pierwsze, prezentację struktury granic władzy prawniczej sprowadzamy do niezbędnego minimum, szeroko została ona bowiem przez nas omówiona w innej pracy ${ }^{8}$. Po drugie, naszym celem nie jest dokonanie kompleksowej

Numer ORCID: 0000-0002-9562-4419. Adres e-mail: pawel.jablonski@uwr.edu.pl

Numer ORCID: 0000-0002-3436-4043. Adres e-mail: przemysław.kaczmarek@uwr.edu.pl

Kiedy wysyłaliśmy niniejszy artykuł do Redakcji „Archiwum Filozofii Prawa i Filozofii Spolecznej”, liczyliśmy na to, że będziemy mogli przedyskutować jego treść z głównym twórcą omawianej przez nas koncepcji - Profesorem Maciejem Zielińskim. Głos Profesora zawsze zawierał cenne i konstruktywne uwagi, o czym wielokrotnie przekonaliśmy się w przeszłości. Jesteśmy pewni, że nie inaczej byłoby tym razem.

4 Z. Ziembiński, Tworzenie a stanowienie i stosowanie prawa, „Ruch Prawniczy, Ekonomiczny i Socjologiczny” 1993/4, s. 44-45.

5 M. Zieliński, M. Zirk-Sadowski, Klaryfikacyjność i derywacyjność w integrowaniu polskich teorii wyktadni prawa, „Ruch Prawniczy, Ekonomiczny i Socjologiczny” 2011/2, s. 110.

6 Za lekturę tekstu oraz przekazanie nam wnikliwych i cennych uwag dziękujemy Pani Prof. Agnieszce Choduń oraz Panu Prof. Włodzimierzowi Gromskiemu.

7 P. Jabłoński, P. Kaczmarek, Granice wtadzy prawniczej w perspektywie polskiej tradycji socjologicznej, Kraków 2017.

8 P. Jabłoński, P. Kaczmarek, Granice władzy..., s. 15-22. 
i wyczerpującej analizy modelu derywacyjnego, lecz wskazanie kilku interesujących nas tropów i pytań.

Derywacyjna koncepcja wykładni prawa stanowi interesujący i ważny punkt odniesienia dla zagadnienia granic władzy prawniczej z kilku względów ${ }^{9}$. Po pierwsze, wydaje się, że jest to obecnie najbardziej wpływowa polska teoria wykładni. Przejawia się to nie tylko w tym, że twórczo nawiązują do niej kolejni rodzimi badacze - jak np. Leszek Leszczyński, Ryszard Sarkowicz, Marcin Matczak, Agnieszka Choduń, Andżelika Godek czy Olgierd Bogucki - bądź to ją rozwijając, bądź to adaptując do własnych konstrukcji, lecz również w tym, że stanowi ona rdzeń budowanej zintegrowanej teorii wykładni.

Po drugie, koncepcja ta posiada otwarty charakter, co znajduje swój wyraz we włączaniu we własne struktury adaptacyjnie zmodyfikowanych elementów innych teorii wykładni, jak np. klaryfikacyjnej czy poziomowej. Bardzo obiecującym aspektem wspomnianej otwartości modelu derywacyjnego jest jego widoczne w ostatnich latach nawiązywanie do hermeneutycznej tradycji myślenia i uznanie, że może ona być integrowana z tym modelem bez naruszania jego spójności ${ }^{10}$. Jest to szczególnie interesujące z punktu widzenia zadania zakreślonego w tym artykule, gdyż hermeneutyka - co przyznaje też główny twórca koncepcji derywacyjnej, Maciej Zieliński ${ }^{11}$ - przyjmuje znaczny wpływ interpretatora na kształt interpretacji, nie czyniąc jej zarazem czymś dowolnym. Wykładnia jest więc pewnego rodzaju grą między tekstem a różnie ujmowanym interpretatorem $^{12}$. Figura gry oraz związek modelu derywacyjnego $\mathrm{z}$ hermeneutycznym ujęciem interpretacji są widoczne w poświęconej temu modelowi monografii wspomnianej już A. Choduń ${ }^{13}$. Istotnym świadectwem otwartego charakteru derywacyjnej teorii jest też jej aplikowalność do nowych wyzwań społeczno-prawnych, w tym do multicentryczności współczesnego prawa oraz związanego z tym przenikania się polskiego porządku prawnego z prawem Unii Europejskiej ${ }^{14}$.

Po trzecie, mocno rozbudowany i zarazem normatywny charakter tej koncepcji sprawia, że można na nią spojrzeć jak na rodzaj złożonej odpowiedzi na pytanie o to, czym prawnik powinien czuć się ograniczony w procesie interpretacji. Jak trafnie zauważa Tomasz Pietrzykowski:

Derywacyjne ujęcie wykładni można traktować jako nie tylko pogląd na właściwy sposób dokonywania interpretacji prawa, lecz jako kompleksową i intelektualnie wyrafinowaną koncepcję metodologiczną nauki prawa. Na podłożu założenia racjonalnego prawodawcy buduje bowiem pewną spójną i całościową wizję właściwego sposobu działania prawnika dążącego do ustalenia treści obowiązujących norm prawnych $^{15}$.

\footnotetext{
9 W niniejszym artykule posługujemy się zamiennie terminami: „teoria”, „koncepcja” i „model”. Jakkolwiek zdajemy sobie sprawę, że kryje się za tym pewne uproszczenie, to wydaje się, iż z punktu widzenia interesujących nas tu spraw nie ma ono istotnego znaczenia. W kwestii sygnalizowanych odmienności, zob. R. Sarkowicz, Uwagi o wspótczesnej interpretacji prawniczej, w: S. Wronkowska (red.), Polska kultura prawna a proces integracji europejskiej, Kraków 2005, s. 16-19.

10 Zob. M. Zieliński, M. Zirk-Sadowski, Klaryfikacyjność..., s. 100-101.

11 M. Zieliński, Wyktadnia prawa. Zasady - reguty - wskazówki, Warszawa 2017, s. 85. To wydanie książki stanowi dla nas podstawowy punkt odniesienia w przedstawianiu derywacyjnej koncepcji wykładni prawa.

12 Postać interpretatora można, naszym zdaniem, odnieść do: 1) konkretnego jurysty, 2) prawniczej wspólnoty interpretacyjnej, a także 3) wspólnoty prawno-politycznej.

13 A. Chodun, Aspekty językowe derywacyjnej koncepcji wyktadni prawa, Szczecin 2018, s. 33.

14 Zob. A. Bator, O adekwatności zatożeń derywacyjnej koncepcji wyktadni do badań nad interpretacja prawa Unii Europejskiej, „Studia Prawa Publicznego” 2015/2, s. 11-34; A. Godek, Czy koniec teorii wyktadni prawa? Kilka uwag o możliwych rozwinięciach derywacyjnej koncepcji wyktadni Macieja Zielińskiego na wyktadnię prawa w sferze postakcesyjnej $z$ wewnętrznej perspektywy interpretacyjnej, w: P. Jabłoński (red.), Czy koniec teorii prawa? Z zagadnień teorii i filozofii prawa, Wrocław 2011.

15 T. Pietrzykowski, Naturalizm i granice nauk prawnych. Esej z metodologii prawoznawstwa, Warszawa 2017, s. 90.
} 
Po czwarte wreszcie, wypracowane przez M. Zielińskiego ujęcie wykładni należy do najbardziej oryginalnych i refleksyjnie rozwijanych konstrukcji polskiej teorii prawa. Dostarcza ono przy tym rozbudowaną siatkę pojęciową, odpowiednią - na co zwraca uwagę M. Matczak ${ }^{16}$ - do uchwytywania dyskursywności reguł prawnych, co wydaje się być czymś rzadkim również w skali światowego prawoznawstwa.

\section{Struktura granic władzy prawniczej}

Tyle o powodach, dla których derywacyjna koncepcja wykładni wydaje nam się ważnym punktem odniesienia przy myśleniu o granicach władzy prawniczej. Teraz parę słów na temat samych tych granic. Przyjmujemy, że mają one następującą strukturę: 1) kultura polityczno-prawna; 2) tekst prawny; 3 ) kultura prawnicza; 4) indywidualne wyczucie aksjologiczne. Przez kulturę polityczno-prawną rozumiemy cechującą dane społeczeństwo moralność polityczną, dostarczającą podstawowych ram aksjologicznych. Jakkolwiek w dużym stopniu jest ona „utekstowiona” w konstytucji, to wyodrębnienie jej jako osobnej granicy wydaje się niezbędne. Jednym z podstawowych powodów jest konieczność uniknięcia akceptacji sprzecznego ze współczesnym sposobem pojmowania prawa twierdzenia, według którego prawodawca może, przy zachowaniu odpowiednich procedur (a mówiąc precyzyjniej - że mógłby, gdyby nie prawo międzynarodowe i ponadnarodowe) kształtować porządek prawny w absolutnie dowolny sposób, a więc np. zmienić konstytucję tak, by godność ludzka była atrybutem przyznawanym i odbieranym indywidualnie przez specjalną jednostkę administracji publicznej. Tekst prawny utożsamiamy natomiast z przepisami prawnymi. Kulturę prawniczą ujmujemy z kolei jako związany ze społecznym podziałem pracy, zakorzeniony w tradycji jurydycznej zespół wiedzy i umiejętności niezbędny do poprawnego stosowania prawa. Wreszcie indywidualne wyczucie aksjologiczne to czynnik łączący się z osobowością interpretatora, jego sądami etycznymi oraz związanymi z poczuciem smaku wartościowaniami estetycznymi. Czynnik ten może być ujmowany bądź to w sposób mocniejszy, w którym oznacza dopuszczenie do głosu osobistych preferencji aksjologicznych interpretatora, bądź to w sposób słabszy, gdzie mowa tylko o indywidualnych próbach rozpoznawania interpretacyjnie spornych treści tekstu prawnego, a także wymogów kultur polityczno-prawnej i prawniczej.

Przyjmujemy przy tym, że między tak wyodrębnionymi granicami zachodzą dwie relacje - dopełniania i korekty ${ }^{17}$. Pierwsza polega na tym, że każda kolejna granica działa - co do zasady - w ramach pozostawionych przez wcześniejsze. Ujmując to od drugiej strony, każda wcześniejsza granica tworzy pewną pierwotną faktyczność, określającą warunki i możliwości działania granic późniejszych. Relacja korekty polega natomiast na tym, że w wyjątkowych sytuacjach granica późniejsza może dostarczyć argumentów na rzecz wyłamania się z ram, wynikających z wcześniejszej, przy czym warunkiem takiego wyłamania się jest pozostanie w zgodności z pozostałymi dwiema granicami. Przykładowo, kultura prawnicza zna coś takiego jak argumentacja contra legem, zaś prawnik, jeśli ma dobre

16 Zob. M. Matczak, Dwupoziomowość języka prawnego w derywacyjnej koncepcji wyktadni i jej znaczenie dla wspótczesnych sporów w anglosaskiej interpretacji prawniczej, w: A. Choduń, S. Czepita (red.), W poszukiwaniu dobra wspólnego. Ksiega jubileuszowa Profesora Macieja Zielińskiego, Szczecin 2010, s. 129-140; M. Matczak, Imperium tekstu. Prawo jako postulowanie i urzeczywistnianie świata możliwego, Warszawa 2019, s. 67-68, 123.

17 W tym kontekście możemy chyba mówić o swobodnej inspiracji bardzo interesującymi ustaleniami merytorycznymi i terminologicznymi poczynionymi przez Tomasza Gizbert-Studnickiego, a dotyczącymi wykładni celowościowej. Zob. T. Gizbert-Studnicki, Wykładnia celowościowa, „Studia Prawnicze”1985/3-4, zwłaszcza s. 61-64. 
argumenty, może próbować przełamywać pewne panujące w praktyce orzeczniczej i doktrynie prawniczej sposoby interpretowania, czy - podchodząc do tego szerzej - sposoby działania. Według zarysowanego wyżej schematu, przełamująca tekst kultura prawnicza powinna mieć wsparcie w kulturze polityczno-prawnej i poczuciu odpowiedzialności poszczególnych jurystów, zaś prawnik, przełamujący jakiś przyjęty przez kulturę prawniczą sposób postępowania, powinien mieć mocne dodatkowe argumenty z zakresu wartości kultury polityczno-prawnej oraz brzmienia tekstu prawnego.

Warto dodać, że opisywana gra między różnymi granicami dotyczy tylko takich sytuacji, w których prawo jest traktowane poważnie, a więc zasadniczo wszystko to odnosi się do realiów państwa prawa. Jasne jest dla nas, że w systemach autorytarnych, cechujących się fasadowością prawa, opisywane granice są - $\mathrm{z}$ wyjątkiem może tekstu prawnego - niszczone, zaś sam tekst, pozbawiony oparcia w pozostałych elementach struktury, przestaje mieć znaczenie ${ }^{18}$.

Przy pierwszym spojrzeniu na derywacyjną koncepcję wykładni może się wydawać, że tekst prawny wyznacza tu całość możliwości działań interpretacyjnych prawnika, co by oznaczało, iż już w punkcie wyjścia między zarysowaną wyżej strukturą a modelem derywacyjnym istnieje sprzeczność. Wrażenie to potęguje fakt, że koncepcja ta przyjmuje, iż: „zasady postępowania interpretacyjnego wyznaczone są nie przez czyjekolwiek zachowania się interpretacyjne, lecz przez rzeczywiste cechy tekstów prawnych, które odpowiednio rozpoznane narzucają taki, a nie inny sposób postępowania interpretacyjnego"19. Trzeba jednak zauważyć, że owo jednostronne zakorzenienie we właściwościach tekstu zostało później zmodyfikowane na rzecz stanowiska, według którego wzorzec wykładni powinien czerpać zarówno z właściwości tekstów prawnych, jak i z dorobku kultury prawniczej, w tym utrwalonych sposobów działania najwyższych organów sądowych ${ }^{20}$. Niezależnie od tej modyfikacji, będziemy się starali pokazać, że rekomendowany przez derywacyjne ujęcie wykładni sposób postępowania pozostawia miejsce dla tego, co w przedstawionej wyżej strukturze pełni funkcję granic nietekstowych. W tym celu potrzebna jest realizacja dwóch dopełniających się zadań. Z jednej strony, będziemy próbowali dokonać „osłabienia” tekstu, tj. wyeksponować to, że na gruncie teorii derywacyjnej jedną z owych wyznaczających sposób postępowania interpretacyjnego właściwości tekstów jest ich niezdolność do pełnego zdeterminowania kształtu interpretacji. $Z$ drugiej zaś strony, będziemy się starali dokonać „wzmocnienia” pozostałych granic, tj. odsłonić kilka momentów, w których wyraźnie zaznaczają one swoją obecność. Nie tyle jednak chodzi nam o próbę modyfikacji modelu derywacyjnego, ile o pewną pracę interpretacyjną, dokonywaną w ramach poruszania się po jego strukturach teoretycznych.

\section{Ogólna charakterystyka derywacyjnej koncepcji wykładni prawa}

Derywacyjną koncepcję wykładni prawa można najogólniej scharakteryzować za pomocą czterech podstawowych założeń. Po pierwsze, jakkolwiek rodziła się ona w oparciu

18 Zob. A. Podgórecki, Mega-sociology, Warszawa 2016, s. 67-69; L. Leszczyński, Wykładnia prawa - model ogólny, w: A. Kalisz, L. Leszczyński, B. Liżewski, Wyktadnia prawa. Model ogólny a perspektywa Europejskiej Konwencji Praw Cztowieka i prawa Unii Europejskiej, Lublin 2011, zwłaszcza s. 60-66.

19 M. Zieliński, Derywacyjna koncepcja wyktadni jako koncepcja zintegrowana, „Ruch Prawniczy, Ekonomiczny i Socjologiczny" 2006/3, s. 95.

20 M. Zieliński, Wyktadnia..., s. 199, 217, 220. Zob. też M. Zieliński, O. Bogucki, A. Choduń, S. Czepita, B. Kanarek, A. Municzewski, Zintegrowanie polskich koncepcji wyktadni prawa, „Ruch Prawniczy, Ekonomiczny i Socjologiczny” 2009/4, s. 24. 
o analizę właściwości tekstów prawnych, to obecnie - jak już wspominaliśmy - czerpie zarówno z nich, jak i z utrwalonej praktyki podmiotów zajmujących się profesjonalną obsługą prawa. Niezależnie jednak od otwierania się koncepcji na rozwiązania wypracowane przez praktykę, jej rdzeniem pozostaje związane z właściwościami tekstów prawnych, wprowadzone przez Z. Ziembińskiego rozróżnienie na przepis prawny i normę prawną ${ }^{21}$. Dystynkcja ta, wskazywana jako fundament całej szkoły poznańsko-szczecińskiej22, wyznacza bardzo interesujący i dobrze wpisujący się w tradycję kontynentalną paradygmat myślenia o prawie ${ }^{23}$.

Po drugie, derywacyjna koncepcja zakłada, że rozumienie tekstu prawnego zawsze wymaga interpretacji, co łączy się nie tylko ze specyfiką tego tekstu, ale też z traktowaniem prawa jako przedmiotu kulturowego ${ }^{24}$.

Trzecie z założeń dotyczy sekwencyjnego charakteru wykładni. Zgodnie z nim wykładnia składa się z następujących po sobie i zarazem częściowo się przenikających faz (porządkującej, rekonstrukcyjnej i percepcyjnej), zaś każda z faz łączy się jeszcze z określoną chronologią stosowania dyrektyw interpretacyjnych.

Czwarte założenie dotyczy zastosowania koncepcji derywacyjnej. Jest ona uniwersalistyczna w dwojakim tego słowa znaczeniu $\left.{ }^{25}: 1\right)$ można ją przedstawiać zarówno jako koncepcję doktrynalną, jak i operatywną, w tym przynajmniej sensie, że ukierunkowana jest ona na bycie aplikowalną w praktyce orzeczniczej; 2) można ją odnieść do różnych dziedzin prawa oraz profesji prawniczych.

Koncepcja derywacyjna została zainicjowana ustaleniami poczynionymi przez Z. Ziembińskiego, a następnie opracowana i rozwinięta przez M. Zielińskiego ${ }^{26}$. Zdaniem drugiego z wymienionych autorów, można wyróżnić dwie fazy kształtowania się tej koncepcji ${ }^{27}$. Pierwszą z nich charakteryzuje indywidualizacja, a drugą - integracja.

Fazę indywidualizacji, trwającą do połowy lat 90. ub. w., znamionuje m.in. czas konfrontacji między derywacyjną a klaryfikacyjną koncepcją wykładni prawa. Zagadnienie relacji między nimi stało się przedmiotem analizy Krzysztofa Płeszki oraz Tomasza GizbertStudnickiego w opracowaniu Dwa ujęcia wyktadni prawa. Próba konfrontacji ${ }^{28}$. Krakowscy teoretycy wskazali w nim na podstawowe zbieżności oraz różnice między derywacyjną a klaryfikacyjną koncepcją wykładni prawa. Jakkolwiek artykuł ten wydaje się być najczęściej przywoływanym komentarzem do koncepcji derywacyjnej, to warto zauważyć, że sami jego autorzy odnotowują dziś konieczność weryfikacji poczynionych tam konstatacji, co jest związane $z$ ewoluowaniem ujęcia derywacyjnego ${ }^{29}$.

21 Z. Ziembiński, Przepis prawny i norma prawna, „Ruch Prawniczy, Ekonomiczny i Socjologiczny” 1960/1, s. 105-122.

22 S. Czepita, S. Wronkowska, M. Zieliński, Zatożenia szkoty poznańsko-szczecińskiej w teorii prawa, „Państwo i Prawo” 2013/2, s. 9.

23 Zob. L. Nowak, Zygmunta Ziembińskiego koncepcja interpretacji. Pewne komentarze, dopetnienia i aplikacje, w: A. Klawitera, L. Nowak, P. Przybysz (red.), Umyst a rzeczywistość, „Poznańskie Studia z Filozofii Humanistyki” 1999/5, numer monograficzny, s. 424-425.

24 M. Zieliński, Wyznaczniki regut wyktadni prawa, „Ruch Prawniczy, Ekonomiczny i Socjologiczny” 1998/3-4, s. 9 i n.; M. Zieliński, Wyktadnia..., s. 57.

25 M. Zieliński, Wyktadnia..., s. 226-229.

26 Zob. M. Zieliński, Interpretacja jako proces dekodowania tekstu prawnego, Poznań 1972; M. Zieliński, Wyktadnia..., s. 77.

27 M. Zieliński, Derywacyjna koncepcja..., s. 93.

28 K. Płeszka, T. Gizbert-Studnicki, Dwa ujęcia wyktadni prawa. Próba konfrontacji, „Zeszyty Naukowe Uniwersytetu Jagiellońskiego. Prace z Nauk Politycznych" 1984/20, s. 17 i n.

29 T. Gizbert-Studnicki, Rozkład ciężaru argumentacji w dyskursie interpretacyjnym, w: J. Stelmach (red.), Studia z filozofii prawa, Kraków 2003, s. 66; K. Płeszka, Wyktadnia rozszerzająca, Warszawa 2010, s. 165 i n. Zob. też M. Zieliński, Mitów w myśleniu o wyktadni prawa ciag dalszy, w: A. Mróz, A. Niewiadomski, M. Pawelec (red.), Prawo, język, media, Warszawa 2011, s. 120-121. 
Jak podkreśla M. Zieliński, od drugiej połowy lat 90 . można zaobserwować powolny proces wygasania postawy konfrontacyjnej między zwolennikami klaryfikacyjnej i derywacyjnej koncepcji wykładni prawa ${ }^{30}$. Procesowi temu towarzyszy poszukiwanie miejsc wspólnych, łączących dwa wymienione ujęcia wykładni. Ideą tego zabiegu jest integrowanie różnych sposobów myślenia o interpretacji ${ }^{31}$. Taki zamiar towarzyszy opracowaniu M. Zielińskiego i M. Zirk-Sadowskiego Klaryfikacyjność i derywacyjność w integrowaniu polskich teorii wyktadni prawa ${ }^{32}$.

Wydaje się, że oprócz wskazanego wyżej integracyjnego kierunku zmian koncepcji derywacyjnej można wskazać jeszcze jedną, istotną cechę jej ewolucji. Najogólniej mówiąc chodzi o pewnego rodzaju pragmatyzację czy też po prostu zwrot w stronę praktyki ${ }^{33}$. $Z$ jednej bowiem strony, sama ta teoria otworzyła się na rozwiązania wypracowane przez orzecznictwo, z drugiej zaś - przepracowała niektóre swoje elementy w taki sposób, by dostosować się do realiów, potrzeb i wymagań praktyki stosowania prawa. Jako przykład takich zmian można podać złagodzenie wymogów jednoznaczności formułowanych wobec normy prawnej, wprowadzenie „momentu interpretacyjnego”, czy też zwiększenie roli wykładni funkcjonalnej.

\section{Niesamoistność tekstu prawnego}

Kluczowym elementem koncepcji derywacyjnej osłabiającym znaczenie tekstu jest bazowanie na rozróżnieniu między przepisem prawnym a normą postępowania ${ }^{34}$. Zakłada ono, że ustalenie znaczenia przepisu prawnego wymaga interpretacji, a wynik procesu wykładni może prowadzić do rezultatu (normy postępowania), który z semiotycznego punktu widzenia różni się od tego, co było przedmiotem wykładni ${ }^{35}$. Przepisy prawne nie są jeszcze samym prawem, lecz „półfabrykatem prawa”. Jakkolwiek pozostają one głównym czynnikiem determinującym treść obowiązujących norm prawnych, to nie rozstrzygają wszystkiego. Są one raczej początkiem „gry w prawo”, a nie jej wynikiem. Jak czytamy: „Akty normatywne i przepisy prawne nie są prawem; prawo jest odtwarzane $\mathrm{z}$ przepisów w procesie wykładni" ${ }^{36}$. Koncepcja ta zakłada, że „treść językowa przepisów prawnych jest istotnym wyznacznikiem treści wyinterpretowanych $w$ procesie wykładni norm, ale nie jest bynajmniej wyznacznikiem jedynym" ${ }^{37}$. Jak stwierdza się w kluczowym z punktu widzenia interesującej nas kwestii fragmencie:

Chyba jednak rzadko która szkoła teoretyczna akcentuje równie mocno, że treść prawa, jako zespołu norm, jest wyznaczana także przez inne niż brzmienie przepisów czynniki; szkoła precyzyjnie identyfikuje owe czynniki i wskazuje sposoby ich oddziaływania, a przy tym głosi, iż - ze względu na założenia przyjmowane współcześnie w polskiej kulturze prawnej - cele

${ }_{30}$ M. Zieliński, Derywacyjna koncepcja..., s. 93.

${ }_{31}$ Zob. M. Zieliński, O. Bogucki, A. Choduń, S. Czepita, B. Kanarek, A. Municzewski, Zintegrowanie polskich ...; M. Zieliński, M. Zirk-Sadowski, Klaryfikacyjność..., s. 99 i n.

${ }_{32}$ M. Zieliński, M. Zirk-Sadowski, Klaryfikacyjność..., passim.

${ }_{33} \mathrm{Na}$ aspekt ten zwraca uwagę: L. Leszczyński, Wyktadnia operatywna (podstawowe wtaściwości), „Państwo i Prawo” 2009/6, s. 18-20.

${ }^{34}$ M. Zieliński, Wykładnia..., s. 17.

M. Zieliński, Wyktadnia..., s. 77

${ }^{6}$ S. Czepita, S. Wronkowska, M. Zieliński, Założenia szkoty..., s. 10.

7 S. Czepita, S. Wronkowska, M. Zieliński, Zatożenia szkoty ..., s. 10. 
i inne wartości, do których odwołujemy się w procesie wykładni, odtwarzać należy przede wszystkim z tekstu prawnego ${ }^{38}$.

Sposób dalszego opracowywania tego „półfabrykatu”, a więc ustalanie jakie dokładnie przepisy i w jakim brzmieniu trzeba wziąć pod uwagę (faza porządkująca), jakie wyrażenia normokształtne należy z nich odtworzyć (faza rekonstrukcyjna) i wreszcie jakie normy wyklarować z tych ostatnich (faza percepcyjna) ${ }^{39}$ - wszystko to rozgrywa się poza tekstem prawnym, choć w ścisłym z nim związku.

Niesamoistność tekstu prawnego (a mówiąc precyzyjniej: niesamoistność znaczenia tekstu prawnego) widoczna jest nie tylko przy stosowaniu reguł systemowych i funkcjonalnych oraz tych, które, za Jerzym Wróblewskim, często określa się jako reguły drugiego stopnia $^{40}$, lecz również przy używaniu reguł wykładni językowej, jako że one same - poza sytuacjami wyjątkowymi (np. związanymi z definicjami legalnymi) - nie są częścią tekstu prawnego. Co więcej, jak trafnie zwraca uwagę Marek Safjan, związana z teorią derywacyjną zasada omnia sunt interpretanda „zakłada radykalną, wręcz rewolucyjną zmianę w obszarze wykładni semantycznej" ${ }^{41}$. Wydaje się, że zmiana ta bardzo dobrze koresponduje z ustaleniami współczesnej filozofii języka, według których coraz trudniej mówić o czymś takim jak „czysto semantyczne znaczenie”, jako że sama semantyka się pragmatyzuje. Jakkolwiek głoszony przez koncepcję derywacyjną analityczny podział na językowe i pozajęzykowe (w tym systemowe i funkcjonalne) reguły wykładni nie odzwierciedla takiej spragmatyzowanej semantyki, to przyjęcie zasady omnia sunt interpretanda, połączone z możliwością korekty wyników ustaleń poczynionych za pomocą reguł językowych, wydaje się w dużym stopniu wychodzić jej naprzeciw.

Znaczenie niesamoistności tekstu nie ogranicza się też do tego, co w koncepcji derywacyjnej jest określane mianem wykładni uzupełniającej-kreująco ani nawet do wykładni uzupełniającej w ogóle (a więc również uzupełniającej-konsekwencyjnie) ${ }^{42}$, lecz odgrywa ona istotną rolę w całym procesie interpretacji. Trzeba jednak zaznaczyć, że czym innym jest niesamoistność tekstu prawnego i związana z nią konieczność udziału kultury prawniczej oraz konkretnej jednostki w procesie jego interpretacji, a czym innym prawotwórczy charakter tejże interpretacji, który na gruncie koncepcji derywacyjnej jest ograniczony do wspomnianej sytuacji wykładni uzupełniającej-kreująco ${ }^{43}$. W tej sprawie czytamy m.in.: „Dobitnie i stanowczo należy jednak podkreślić, że w żadnym razie nie jest uzasadnione przenoszenie przekonania o prawotwórczym charakterze wykładni (sensu largo) uzupełniającej-kreująco na pozostałe role wykładni”"44.

Takie rozpoznanie i wyeksponowanie progu działalności prawotwórczej, a więc progu interpretacji twórczej, wydaje się nieco problematyczne. Można zaryzykować twierdzenie, że w tym momencie dochodzi w derywacyjnym modelu wykładni do ujawnienia się napięcia między różnymi źródłami ożywiającymi tę koncepcję. Są to z jednej strony jej założenia pozytywistyczno-prawne i naturalistyczne (w sensie ontologicznego i epistemologicznego obiektywizmu czy też - nieco inaczej - w znaczeniu ostrego przeciwstawiania podmiotu

38 S. Czepita, S. Wronkowska, M. Zieliński, Zatożenia szkoty..., s. 11.

39 M. Zieliński, Wyktadnia..., s. 281-302.

40 W kwestii obecności w modelu derywacyjnym reguł drugiego stopnia zob. T. Gizbert-Studnicki, Dyrektywy wyktadni drugiego stopnia, w: A. Choduń, S. Czepita (red.), W poszukiwaniu..., s. 65.

${ }^{41}$ M. Safjan, Uniwersalizacja wyktadni prawa, w: A. Choduń, S. Czepita (red.), W poszukiwaniu..., s. 272.

42 M. Zieliński, Wyktadnia..., s. 208-209.

43 M. Zieliński, Wyktadnia..., s. 209.

44 M. Zieliński, Wyktadnia..., s. 209. 
i przedmiotu poznania) ${ }^{45}$, z drugiej zaś strony hermeneutyczna tradycja filozoficzna, z którą coraz wyraźniej ta koncepcja sympatyzuje. Według ujęcia hermeneutycznego ścisłe separowanie momentów twórczych i odtwórczych w procesie interpretacji jest nieuzasadnione. Ważne jest tu raczej to, czy interpretacja jest odpowiednia z punktu widzenia tradycji, na której bazuje (w tym przypadku dorobku prawoznawstwa i orzecznictwa), możliwości, jakie stwarza tekst oraz problemu praktycznego jaki musi rozwiązać.

Zauważmy, że odwołanie się do argumentu z założenia o racjonalności prawodawcy, które dokonane jest $\mathrm{w}$ celu wsparcia tak ustalonego progu prawotwórstwa ${ }^{46}$ ma naturę obosieczną. Z jednej bowiem strony, z założenia tego rzeczywiście wynika, że w tekście prawnym jest tylko jedno rozwiązanie legislacyjne, odkrywane przez podmiot stosujący $\operatorname{prawo}^{47}$. Z drugiej jednak strony - powstają dwa pytania. Po pierwsze, czy zgoda na taki argument nie powinna skłaniać do uznania, że również interpretacja uzupełniająco-kreująca nie ma charakteru twórczego, jako że przy każdej (a więc i tej) interpretacji prawnik powinien mieć na uwadze ograniczenia wynikające $\mathrm{z}$ założenia o racjonalności prawodawcy? $\mathrm{Z}$ tej perspektywy można powiedzieć, że rozpoznawanie tego, co prawodawca zdecydował, zastępowane jest tu rozpoznawaniem tego, co by zdecydował, gdyby ustanowił odpowiednią regulację. Pewien element kontrfaktyczności obecny jest przecież w obu rozpoznaniach, jako że nie chodzi o odczytanie komunikatu nadanego przez prawodawcę socjologicznego, lecz racjonalnego ${ }^{48}$. Ryzyko „subiektywnych odstępstw od rzeczywistych treści zawartych przez ustawodawcę w danym tekście (przypisie, ustawie)" ${ }^{\prime 9}$ dotyczy przecież i tak treści będących pewnym konstruktem interpretacyjnym, co nie oznacza jednak, że ryzyko to staje się przez to mniej realne, czy mniej niebezpieczne. Używając poręcznego rozróżnienia zaproponowanego przez O. Boguckiego, można powiedzieć, że działania ontologicznie prawotwórcze i zarazem metodologicznie odtwórcze przebiegają po obu stronach wskazanej wyżej granicy ${ }^{50}$. Jakkolwiek najprawdopodobniej nie występują one tam w takim samym natężeniu, to przeprowadzanie w tym miejscu kategorycznej delimitacji wydaje się problematyczne.

Drugie, ważniejsze pytanie, dotyczy statusu tego argumentu wobec nieskrywanej przez Leszka Nowaka i wiadomej teoretykom kontrfaktyczności tego założenia. Skoro bowiem jego treścią jest nie tyle wiara, że rzeczywisty prawodawca jest racjonalny, ile opis (a w wersji zmodyfikowanej: nakaz) interpretowania tekstu prawnego tak, jakby pochodził od prawodawcy racjonalnego, to zbudowany wokół tego argument nie tyle przemawia za oddzieleniem twórczego elementu interpretacji od elementu nietwórczego, ile za odróżnieniem interpretacji arbitralnej od niearbitralnej. Wydaje się więc, że teoretycznie i pragmatycznie bardziej uzasadnionym sposobem legitymizowania prawniczej praktyki interpretacyjnej może dziś być wskazywanie - zgodnie z hermeneutyką - na osłabienie granicy między twórczym i odtwórczym elementem interpretacji niż obrona tej granicy. W takim ujęciu opozycja twórczy-odtwórczy przestaje być klarowna, zaś kluczowe jest

45 Zob. S. Czepita, S. Wronkowska, M. Zieliński, Założenia szkoty..., s. 5-8. Trzeba jednak dodać, że stosunek tej koncepcji (jak i całej szkoły poznańsko-szczecińskiej) do pozytywizmu prawniczego jest złożony, co trafnie wskazują sami przedstawiciele tej formacji. Por. M. Zirk-Sadowski, Pozytywizm prawniczy a filozoficzna opozycja podmiotu i przedmiotu poznania, w: J. Stelmach (red.), Studia ..., passim.

46 M. Zieliński, Wyktadnia..., s. 209.

47 M. Zieliński, Wyktadnia..., s. 209.

48 M. Zieliński, Wyktadnia ..., s. 258-259.

49 M. Zieliński, Podstawowe zasady wspótczesnej wyktadni prawa, w: P. Winczorek (red.), Teoria i praktyka wyktadni prawa, Warszawa 2005, s. 119; M. Zieliński, Wyznaczniki..., s. 11.

50 Zob. O. Bogucki, O sposobach pojmowania twórczego charakteru interpretacji, „Archiwum Filozofii Prawa i Filozofii Społecznej" 2013/1, s. 21-25. 
to, czy wykładnia jest dokonywana zgodnie z regułami sztuki prawniczej, ukierunkowanej na egzegezę obowiązującego tekstu prawnego - czy też z ich pogwałceniem. Przy takim podejściu założenie o racjonalności prawodawcy pozostaje kluczowym elementem samorozumienia praktyki prawniczej i - jak zwraca uwagę Artur Kozak - dostarcza standardów kontroli decyzji interpretacyjnej ${ }^{51}$. Są one łączone jednak nie tyle bezpośrednio z wiernością tekstowi prawnemu, ile z wiernością jurydycznemu sposobowi myślenia, w którym poważne traktowanie tekstu jest istotnym elementem. Warto w tym kontekście przytoczyć trafne spostrzeżenie poczynione przez Andrzeja Batora:

Wszystkie analityczne teorie prawa, a w szczególności normatywne teorie wykładni - do których należy koncepcja derywacyjna - wzmacniają rolę prawnika w faktycznym podziale władzy „ukrywanej” za doktrynalnymi konstrukcjami pojęciowymi, z których podstawową, jak się wydaje, jest właśnie założenie o racjonalności prawodawcy ${ }^{52}$.

Nieco dalej zaś czytamy:

Założenie o racjonalności prawodawcy nie powinno bowiem legitymizować prawa jako prostego instrumentu w rękach jakiegoś jednego, socjologicznego prawodawcy, a przeciwnie, powinno sprzyjać aktywności interpretatora dostosowującego rozumienie tekstu do potrzeb i oczekiwań społecznego kontekstu (sprawy krajowej, sprawy europejskiej), w którym dokonywana jest wykładnia prawa ${ }^{53}$.

Wydaje się więc, że konstrukcja racjonalnego prawodawcy nie tyle dostarcza argumentu za silnym separowaniem tego, co twórcze od tego, co odtwórcze, ile raczej sprzyja dyskursywności prawa. Z jednej strony, zapewnia interpretatorowi „pole manewru” i zwiększa zarazem jego stopień odpowiedzialności za wynik interpretacji. Z drugiej zaś strony, dostarcza podlegających intersubiektywnej kontroli ram argumentacji. W ten sposób kultura prawnicza staje się czynnikiem prowadzącym do częściowej autonomizacji prawa względem polityki ${ }^{54}$. Prawodawca socjologiczny przestaje tu być włodarzem sensu prawa, choć pozostaje jednym z kluczowych graczy. O ile władzę kreowania tekstu prawnego dzieli tylko - a dzielić musi, choćby ze względu na trwanie aktów prawnych w czasie oraz na multicentryczność współczesnego prawa - z innymi prawodawcami socjologicznymi, o tyle nie ma on decydującej władzy nad znaczeniem tego tekstu.

Wydaje się też, że ostre separowanie interpretowania prawa od jego współkreowania pozostaje w pewnym napięciu z ujmowaniem - w naszym przekonaniu bardzo trafnym - derywacyjnej koncepcji wykładni prawa jako takiej, która stwarza miejsce dla prawotwórczej roli nauki prawa i praktyki prawniczej oraz ,zakłada ponadto ujęcie najszerzej rozumianej wykładni (egzegezy) przepisów prawnych jako czynności nie czysto poznawczej, odtwórczej, ale w pewnych aspektach twórczej”'55. Zauważmy, że uzgodnienie tego ze wskazanym wyżej sposobem eksponowania i ustawiania progu działalności prawotwórczej wymagałoby przyjęcia, iż owe aspekty twórcze ograniczają się tylko do wykładni uzupełniająco-kreującej, tj. do tego, co - jak czytamy - najlepiej byłoby wyeliminować poprzez wprowadzenie szybkiej

\footnotetext{
51 A. Kozak, Charakterystyka kategorii „racjonalny prawodawca” w sadowym stosowaniu prawa, w: M. Zirk-Sadowski (red.), Filozoficzno-teoretyczne problemy sq̨dowego stosowania prawa. XII Ogólnopolski Zjazd Katedr Teorii i Filozofii Prawa (Łódź, 8-10 listopada 1996 r.), Łódź 1997, s. 134-135.

52 A. Bator, $O$ adekwatności..., s. 26.

53 A. Bator, $O$ adekwatności..., s. 27.

${ }_{54}$ Zob. W. Gromski, Autonomia prawa jako funkcja kultury prawnej, w: W. Gromski (red.), Z zagadnień teorii i filozofii prawa. Autonomia prawa, Wrocław 2001.

55 S. Czepita, S. Wronkowska, M. Zieliński, Założenia szkoty..., s. 11.
} 
ścieżki legislacyjnej ${ }^{56}$. Tymczasem w naszym przekonaniu teoretyczne wysublimowanie koncepcji derywacyjnej oraz jej praktyczna atrakcyjność polega m.in. na tym, że element kreatywności w dekodowaniu tekstu prawnego nie jest tam czymś marginalnym i zasadniczo eliminowalnym, lecz jest ważnym aspektem interpretacji. Element ten - trzeba to mocno podkreślić - nie oznacza jednak dowolności, lecz jest częścią skomplikowanej gry zachodzącej między tekstem prawnym a szeroko ujmowanym interpretatorem, sama zaś koncepcja derywacyjna jawi się jako propozycja detalicznej i systemowo opracowanej instrukcji tej gry.

Warto też w tym kontekście zauważyć, że sam Z. Ziembiński wydaje się być daleki od ścisłego separowania interpretacji odtwórczej od twórczej. Podkreśla on znaczenie takich elementów procesu stosowania prawa jak: obecność niepodlegającej algorytmizacji decyzji, dokonywanie wartościujących wyborów czy niejednolitość doktryny i orzecznictwa ${ }^{57}$. Jak pisze interesujący nas teoretyk, zadaniem prawników jest przedstawianie „wobec społeczeństwa i wobec funkcjonariuszy aparatu państwowego" ${ }^{58}$ systemu norm prawnych jako spójnego i zwartego, ,chociażby koncepcje faktycznych uczestników procesu prawotwórczego były niespójne, niejasne i wyraźnie nie odpowiadały wyobrażeniom o racjonalności’'59. Zadaniem kultury prawniczej jest więc to, co Jerzy Leszczyński przedstawia jako pozytywizację prawa ${ }^{60}$. Przypomnijmy, że jednym $\mathrm{z}$ aspektów owego procesu jest częściowe zacieranie się granicy między interpretowaniem prawa a jego wspóttworzeniem. Sam zaś Z. Ziembiński podsumowuje swoje rozważania na temat granicy między stosowaniem prawa a jego współtworzeniem następująco:

Kategoria działań, którym przypisuje się charakter prawotwórczy, ma granice rozmyte. Trudno byłoby nawet sformułować taką definicję regulującą, która pozwoliłaby konwencjonalnie wyznaczyć ostry zakres działań o charakterze prawotwórczym, a pewne działania wykazują tego rodzaju charakter w marginalnym tylko, jak się wydaje, stopniu ${ }^{61}$.

Trzeba jednak zdecydowanie podkreślić, że byłoby błędem przyjmować, iż takie stawianie sprawy prowadzi do anarchizmu interpretacyjnego i zmniejszania roli postępowania zgodnego z zasadami wypracowanymi przez kulturę prawniczą, w tym z przyjętymi w niej regułami wykładni. Jest dokładnie odwrotnie: osłabianie statusu ontologicznego prawa zwiększa znaczenie istnienia i przestrzegania reguł prawniczej egzegezy.

Zostawiając już problem prawotwórczego charakteru interpretacji, odnotujmy jeszcze, że przyjęcie bazującej na rozróżnieniu przepisu i normy koncepcji wykładni ma szereg istotnych konsekwencji nie tylko natury teoretycznej, lecz również praktycznej. Przykładowo, w sformułowanym w art. 7 Konstytucji RP ${ }^{62}$ wymogu, według którego: „Organy władzy publicznej działają na podstawie i w granicach prawa”, owo prawo należy rozumieć jako normy właśnie, a nie jako przepisy. Jakkolwiek w systemie prawa stanowionego normy są wyprowadzane z przepisów, to jednak nie każdy element normy będzie zawsze znajdował bezpośrednie odzwierciedlenie w tekście przepisów. Jak zwraca się uwagę w literaturze, takie ujęcia ma istotne znaczenie dla sposobu budowania argumentacji oraz zakresu dopuszczalnej działalności naprawczej interpretacji prawniczej ${ }^{63}$.

\footnotetext{
M. Zieliński, Wyktadnia ..., s. 209.

Z. Ziembiński, Wstęp do aksjologii dla prawników, Warszawa 1990, s. 161. Zob. też A. Kozak, Pojmowanie prawa w teorii wyktadni, Wrocław 1997, s. 48-49.

Z. Ziembiński, Problemy podstawowe prawoznawstwa, Warszawa 1980, s. 274.

Z. Ziembiński, Problemy..., s. 274.

J. Leszczyński, Pozytywizacja prawa w dyskursie dogmatycznym, Kraków 2010.

Z. Ziembiński, Tworzenie..., s. 50.

Konstytucja Rzeczypospolitej Polskiej z 2.04.1997 r. (Dz. U. Nr 78, poz. 483 ze zm.).

Zob. M. Walasik, Analogia w prawie procesowym cywilnym, Warszawa 2013, s. 374-375.
} 
Oprócz właściwości tekstu prawnego związanych bezpośrednio z rozróżnieniem na normy i przepisy (takich jak rozczłonkowanie i kondensacja norm w przepisach) ${ }^{64}$, można wskazać kilka innych tematyzowanych w koncepcji derywacyjnej jego cech, które sprawiają, że wymaga on zabiegów interpretacyjnych. Należy tu wymienić takie m.in. właściwości jak: zmienność, wieloznaczność, występowanie zwrotów niedookreślonych i nieostrych czy też - bardziej ogólnie - zasadniczą otwartość tekstu prawnego ${ }^{65}$. Wraz z docenieniem ostatniego z wymienionych zagadnień, derywacyjne ujęcie wykładni stało się bardziej otwarte na dostrzeganie związanych z interpretacją wątków etycznych ${ }^{66}$.

\section{Sytuacja wykładni a refleksyjność}

Problem sytuacji wykładni jest jednym z tych zagadnień, które wciąż wywołuje dyskusję w polskim prawoznawstwie ${ }^{67}$. Dokumentuje to debata wokół zasady clara non sunt interpretanda. M. Zieliński formułuje wobec wymienionej zasady trzy grupy zarzutów o charakterze odpowiednio: 1) metodologicznym, 2) empirycznym i 3) etycznym ${ }^{68}$. Dla wielu z podnoszonych, w ramach tych zarzutów, argumentów wspólna jest myśl, że rozumienie tekstu prawnego wymaga refleksyjności ${ }^{69}$. W tym kontekście zwróćmy uwagę na słowa M. Zielińskiego:

do dziś nie wiadomo, na czym miałoby polegać rozumienie bezpośrednie (...). Jeśli np. miałoby ono polegać na automatycznym, bezrefleksyjnym percypowaniu treści wyrażenia, a wykładnia, jak wiadomo, niewątpliwie jest zabiegiem refleksyjnym, to w myśl zasady clara non sunt interpretanda, trzeba by w konsekwencji uznać, że bezrefleksyjna pewność co do treści jakiegoś zwrotu stanowiłaby tamę nie do przebycia dla refleksyjnego pozyskania treści (nawet tej samej treści) danego zwrotu ${ }^{70}$.

Rozumienie tekstu prawnego może więc być refleksyjne bądź bezrefleksyjne. Podstaw tego rozróżnienia można upatrywać w procesie poznawczym interpretatora. Jak odnotowuje M. Zieliński, zmienność tekstu prawnego wymaga „czujności i skrupulatności interpretatora, i to zarówno w związku ze zmianami dokonującymi się w wyniku nowelizacji, jak i w związku z naturalną zmiennością znaczeń poszczególnych słów. Bez subtelnie refleksyjnego podejścia do rozumienia trudno by było zapewnić aktualność rozumienia tekstu"71. Jeśli trafnie odczytujemy te słowa, to zwraca się w nich uwagę na co najmniej dwie racje, uzasadniające traktowanie wykładni prawa w kategoriach refleksyjności. Pierwsza z nich związana jest ze zmiennością prawa. W tym aspekcie refleksyjność wykładni ma umożliwić zdolność podążenia za zmianami w prawie. Niemniej jednak refleksyjność nie jest „,konsumowana” przez samą zmienność prawa. Drugą z racji jest bowiem „naturalna zmienność znaczenia poszczególnych słów”. W tym zakresie celem wykładni jest otwarcie znaczenia

${ }^{64}$ M. Zieliński, Wyktadnia..., s. 101-127.

65 Zob. M. Zieliński, Wyktadnia..., s. 128-196.

${ }^{66}$ Zob. M. Zieliński, M. Zirk-Sadowski, Klaryfikacyjność..., s. 110.

67 M. Zieliński, M. Zirk-Sadowski, Klaryfikacyjność..., s. 101-102.

68 M. Zieliński, Clara non sunt interpretanda - mity i rzeczywistość, „Zeszyty Naukowe Sądownictwa Administracyjnego” 2012/6, s. 9-23. Zob. także A. Choduń, Aspekty językowe..., s. 96 i n.; K. Płeszka, Wyktadnia ..., s. 193-197.

69 M. Zieliński, Wyktadnia..., s. 55. Zob. także A. Choduń, M. Zieliński, Aspekty granic wykładni prawa, w: W. Miemiec (red.), Ksiega Jubileuszowa Profesora Ryszarda Mastalskiego. Stanowienie i stosowanie prawa podatkowego, Wrocław 2009, s. 86-87.

70 M. Zieliński, Podstawowe zasady..., s. 119.

71 M. Zieliński, Clara non sunt..., s. 14. 
słów na kontekst systemowy oraz funkcjonalny. O ile bowiem do racji językowych można przyporządkować reguły wykładni językowej, o tyle do racji pozajęzykowych: reguły wykładni systemowej i funkcjonalnej ${ }^{72}$.

Refleksyjność wykładni zakłada zatem wzięcie pod uwagę różnych racji, a w konsekwencji dopuszczenie sytuacji rywalizacji między argumentami, które można zrekonstruować z reguł językowych i pozajęzykowych. Uwzględnia też ona, przy spełnieniu określonych warunków, możliwość odejścia od znaczenia pojęć ustalonych na podstawie wcześniejszych racji, w tym przypadku językowych. Dopuszczenie to jest obwarowane warunkami, przy czym kluczowy wydaje się być ten, który odwołuje się do założenia o racjonalności prawodawcy, zwłaszcza w zakresie spójności przyjętego systemu wartości.

Ważne dla tak rozumianej refleksyjności są dwie cechy ${ }^{73}$. Po pierwsze, samoświadomość prawnika i praktyki interpretacyjnej. Po drugie, samozwrotność postrzegana jako zdolność do rewizji zakładanych racji, problematyzacji rekomendowanego sposobu działania $^{74}$. Jakość wykładni prawa zależy nie tylko od postawy jurysty, ale i kultury interpretacyjnej, która rekomenduje określone działanie. Takie ujęcie refleksyjności wzmacnia również myślenie, zgodnie z którym nie bez znaczenia dla kształtu kultury prawniczej jest to, jacy prawnicy ją tworzą. Spróbujmy teraz obie wymienione cechy refleksyjności (samoświadomość i zwrotność) szerzej odnieść do derywacyjnej koncepcji wykładni prawa.

\section{Refleksyjność jako samoświadomość}

Koncepcja derywacyjna opowiada się zatem za uwzględnieniem w procesie interpretacji reguł językowych, systemowych i funkcjonalnych ${ }^{75}$. W omawianej koncepcji reguły wykładni językowej mają charakter podstawowy, są chronologicznie pierwsze. Nie oznacza to jednak wyłączenia tych racji wykładni, które dotyczą kontekstu systemowego i funkcjonalnego. Co więcej, w omawianej koncepcji mamy do czynienia z obecnością aspektu odnoszenia się do siebie poszczególnych reguł.

Jak podkreślają M. Zieliński i M. Zirk-Sadowski: „Znaczenie jest w istocie grą pomiędzy interpretatorem a szeroko rozumianym tekstem. Interpretacja jako gra oznacza, że nie istnieje tak zwane właściwe rozumienie tekstu"76.

Wskazane pojęcie gry między tekstem a interpretatorem stanowi argument na rzecz modyfikacji analitycznego ujęcia znaczenia tekstu prawnego opisanego przez Tomasza Spyrę. Przypomnijmy, że krakowski badacz wyróżnia dwa standardowe ujęcia znaczenia tekstu ${ }^{77}$. Pierwsze z nich - analityczne - zakłada, że znaczenie jest obecne w samym tekście, zaś interpretator je tylko wydobywa. Z kolei drugie ujęcie podkreśla, że nie ma czegoś takiego jak czekające na wydobycie, ustabilizowane znaczenie tekstu, jest więc ono raczej czymś, co współtworzy się w procesie interpretacji. Ujęcie to podkreśla niesamoistność tekstu prawnego.

72 M. Zieliński, Wykładnia ..., s. 210. O trzech typach wykładni jako kontekstach zob. J. Leszczyński, Pozytywizacja..., s. 224 in.

73 Zob. M. Pichlak, Refleksyjność prawa. Od teorii spotecznej do strategii regulacji i z powrotem, Łódź 2019, zwłaszcza s. 24-27.

74 Anthony Giddens stwierdza: „Wykształcenie samozwrotnych systemów społecznych leży u podstaw refleksyjnego projektu tożsamości”. A. Giddens, Nowoczesność i tożsamość. „Ja” i spoteczeństwo w epoce późnej nowoczesności, Warszawa 2010, s. 197.

75 M. Zieliński, Wyktadnia..., s. 210.

76 M. Zieliński, M. Zirk-Sadowski, Klaryfikacyjność..., s. 110.

77 T. Spyra, Granice wyktadni prawa. Znaczenie językowe tekstu prawnego jako granica wyktadni, Kraków 2006, s. 173-183. 
Próba przedstawiania procesu wykładni jako pewnej formy gry zakłada nie tylko określone stanowisko w zakresie ontologii tekstu prawnego, ale i kultury prawniczej. W tym świetle odczytujemy słowa M. Zielińskiego i M. Zirk-Sadowskiego: ,przyjęcie zasady omnia sunt interpretanda (...) uświadamia prawnikowi również jego specyficzną sytuację egzystencjalną, a nie jest tylko praktyczną wskazówką interpretacyjną"78. Sytuacja ta jest ważnym powodem do traktowania refleksyjności nie tylko w ujęciu indywidualnym, ale także jako kategorii kultury prawniczej. W celu zachowania na poziomie instytucjonalnym samoświadomości prawników, kluczowe staje się kształtowanie podmiotowości wykonawcy roli na czynniku intersubiektywnym (np. kulturze prawniczej) oraz jednostkowym (moralności indywidualnej). Mając na uwadze wskazany dualizm wyłania się obraz prawnika, który można rozrysować za pomocą kategorii podwójnej spirali Jean-Claude Kaufmanna ${ }^{79}$. Zakłada ona, że tożsamość jednostki można przedstawić za pomocą dwóch modalności: habitusu społecznego oraz indywidualizacji. Pierwsza z nich podkreśla instytucjonalny wymiar tożsamości. Modalność ta akcentuje, że wykonywanie roli, proces wykładni nie jest swobodnym działaniem, ale jest wyrazem kompetencji komunikacyjnej, nabytej w drodze edukacji. Z kolei druga modalność eksponuje znaczenie subiektywności, indywidualności w procesie kształtowania się tożsamości jednostki. W tym ujęciu postawę refleksyjną charakteryzuje zachowanie samoświadomości przez prawnika, jako członka wspólnoty interpretacyjnej. To, na ile postawa ta ma charakter jednostkowy, a na ile jest wymogiem stawianym przez wspólnotę interpretacyjną, zależy od kultury prawniczej. Z tego powodu relacje prawnik-kultura prawnicza można przedstawić za pomocą relacji dopełnienia. Zgodnie z nią, kultura ma wpływ na tożsamość prawników, ale i podmiotowość interpretatora, jego sposób działania kształtuje postać kultury prawniczej. W relacji tej nie zanika ani podmiotowość interpretatora, ani specyfika kultury prawniczej.

W tym odczytaniu samoświadomość prawnika oraz wspólnoty interpretacyjnej staje się jedną z granic wykładni mającą wpływ na sposób odczytania tekstu prawnego ${ }^{80}$. Jak zauważa A. Choduń w derywacyjnej koncepcji wykładni postawa interpretatora nie jest postawą odtwórczą: „Interpretator nie odkrywa bowiem znaczeń, ale je ustala, choćby dlatego, że dokonuje wyboru znaczenia, i to nie tylko w sytuacji wieloznaczności leksykalnej. Nie jest to jednak ustalenie o charakterze subiektywnym według własnego uznania" ${ }^{\text {. }}$.

\section{Refleksyjność jako rewizyjność}

Refleksyjność rozumiana jako samoświadomość zakłada również potencjalną rewizyjność posługiwania się regułami wykładni prawa. Celem podważalności rezultatu interpretacji językowej jest zapobiegnięcie złemu prawu w sensie technicznym oraz aksjologicznym. Taką możliwość zapewnia derywacyjna koncepcja wykładni prawa.

$\mathrm{Na}$ pierwszy z wymienionych aspektów zwraca uwagę M. Zieliński, podkreślając naprawczą rolę wykładni, a także rolę uzupełniająco-kreującą 82 . Powodem konieczności ich przeprowadzania są odpowiednio błędy redakcyjne tekstu prawnego i niedopatrzenia legislacyjne ${ }^{83}$.

78 M. Zieliński, M. Zirk-Sadowski, Klaryfikacyjność..., s. 110.

79 J.-C. Kaufmann, Kiedy Ja jest innym. Dlaczego i jak coś się w nas zmienia, Warszawa 2013, s. 122 i n. Zob. także P. Kaczmarek, Dystans do roli w zawodzie prawnika, Warszawa 2019, s. 105.

80 Zob. A. Choduń, M. Zieliński, Aspekty granic..., s. 91.

81 A. Choduń, Aspekty językowe..., s. 34.

82 M. Zieliński, Wyktadnia..., s. 206-209.

83 M. Zieliński, Wyktadnia..., s. 206, 208. Zob. też M. Smolak, Wyktadnia celowościowa z perspektywy pragmatycznej, Warszawa 2012, s. 57-58. 
Natomiast drugi z wymienionych przypadków można odnieść do sytuacji konfliktu między poszczególnymi racjami. Taka sytuacja, jak podkreśla M. Zieliński, ,prima facie może być teoretycznie rozwiązana na dwa sposoby - albo odrzuci się rezultat wykładni funkcjonalnej, albo odrzuci się rezultat wykładni językowej"s4. M. Zieliński wskazuje jednak w tym kontekście na rosnące znaczenie trzeciego - pośredniego - rozwiązania: ,jeśli w przypadku konfliktu rezultatów wykładni funkcjonalnej i językowej okaże się, że rezultat uzyskany w oparciu o reguły językowe burzy podstawowe założenia aksjologiczne o prawodawcy (zwłaszcza o jego systemie wartości), to należy dać pierwszeństwo rezultatowi uzyskanemu na gruncie zastosowania regul funkcjonalnych" ${ }^{\prime 5}$. Rozwiązanie to przedstawia zatem przesłanki, które uzasadniają przełamanie wykładni językowej. Omawiane ujęcie różni się od pozostałych dwóch tym, że mamy w nim do czynienia z aspektem odnoszenia się reguł wykładni, który wymaga ważenia poszczególnych racji.

Przełamanie wykładni językowej może być słabe albo mocne ${ }^{86}$. Z pierwszą z sytuacji mamy do czynienia w przypadku, gdy dokonanie wykładni językowej ujawnia różne możliwe rozwiązania. W takiej sytuacji wykładnia funkcjonalna ,służy dokonaniu wyboru jednego z nich jako właściwego"s7. Z kolei drugie z ujęć znamionuje rozwiązanie, które sugeruje danie pierwszeństwa rezultatowi, który został ustalony na podstawie reguł wykładni funkcjonalnej. Wskazane dwa ujęcia podważalności można odnieść do dwóch typów uzasadnień o charakterze odpowiednio optymalizacyjnym i gwarancyjnym, które omawia O. Bogucki ${ }^{88}$. $\mathrm{Z}$ racją optymalizacyjną mamy do czynienia wtedy, gdy zadaniem wykładni funkcjonalnej jest wybór najlepszego z dostępnych na poziomie językowym rozwiązań. $Z$ kolei z uzasadnieniem gwarancyjnym mamy do czynienia w sytuacji, gdy celem wykładni funkcjonalnej staje się zapobiegnięcie rezultatowi wykładni językowej, który możemy określić jako zły aksjologicznie ${ }^{89}$.

Problem rewizji rezultatu wypracowanego na podstawie wykładni językowej opisują proponowane przez M. Zielińskiego reguły wykładni:

REGUŁA 39: W przypadku gdy językowe znaczenie burzy określone wartości, należy:

1) wskazać, o które wartości chodzi;

2) wskazać, na czym polega uznanie ich za podstawowe (niewzruszalne).

REGUŁA 40: W sytuacji gdy znaczenie językowe burzy owe zidentyfikowane niewzruszalne wartości, należy tak zmieniać językowo jasne znaczenie interpretowanego zwrotu, aby została zapewniona spójność aksjologiczna (wykładnia rozszerzająca albo zwężająca) ${ }^{90}$.

Przełamanie argumentu wypracowanego na podstawie reguł językowych na rzecz argumentacji pozatekstowej odsłania ważny aspekt sprawczego charakteru interpretacji, a także grę między poszczególnymi czynnikami mającymi wpływ na wykładnię prawa ${ }^{91}$. W jej zakresie mamy do czynienia ze złożoną relacją zachodzącą między poszczególnymi racjami działania. Kolejność racji w obrębie derywacyjnej koncepcji nie jest przypadkowa ${ }^{92}$.

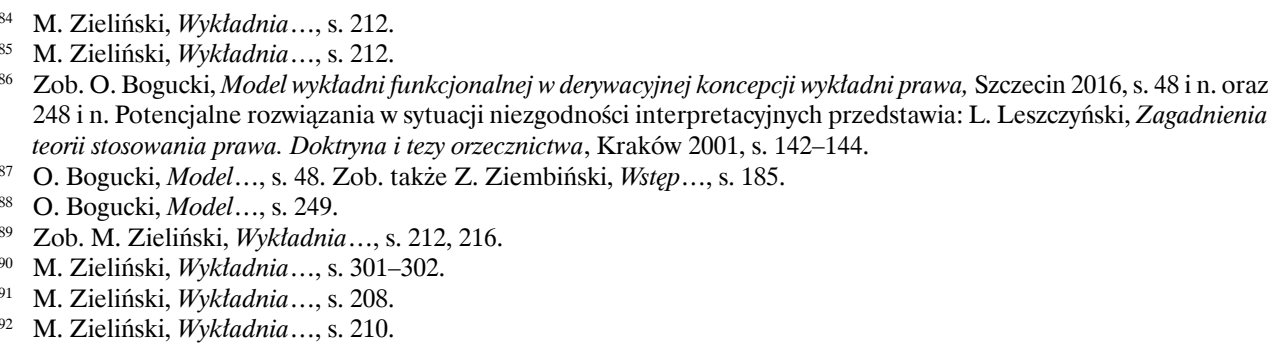


Wyłaniająca się z omawianej koncepcji topografia reguł wykładni (językowych, systemowych i funkcjonalnych) wyznacza rekomendowany sposób działania prawnika, ale jednocześnie tworzy możliwość przełamania znaczenia językowego. Odnotujmy w tym miejscu, że M. Zieliński wyróżnia dwie sytuacje przełamania językowego znaczenia tekstu prawne$\mathrm{go}^{93}$. Pierwsza z nich jest dokonywana z perspektywy tego, co my nazywamy kulturą prawniczą - w tym zakresie kluczową funkcję pełnią reguły wykładni funkcjonalnej. $\mathrm{Z}$ kolei druga $z$ sytuacji podstaw rewizji upatruje w systemie prawnym. Ustalenia te potwierdzają, że derywacyjna koncepcja wykładni prawa zakłada możliwość sytuacji rewizji znaczenia budowanego na podstawie wcześniejszych racji.

Zagadnienie rewizji reguł wykładni, w nawiązaniu do koncepcji derywacyjnej, podejmuje J. Leszczyński. Zdaniem łódzkiego teoretyka, interpretator dokonując wykładni systemowej i funkcjonalnej „niejako dobiera metodycznie znaczenia do okoliczności zewnętrznych"94. Zewnętrznego kontekstu wobec językowego znaczenia pojęć dostarcza system prawny (wykładnia systemowa) i kultura prawnicza (wykładnia funkcjonalna). Sytuację rewizji znaczenia językowego dokonywaną na podstawie wykładni funkcjonalnej przedstawia także Marek Smolak, wskazując, że kontekst funkcjonalny można rozpatrywać szerzej, wychodząc poza aspekt kultury prawniczej95. Mając na uwadze ustalenia poznańskiego filozofa prawa, można w obrębie kontekstu funkcjonalnego wyróżnić również czynniki składające się na kulturę polityczno-prawną ${ }^{96}$. Obaj wymienieni badacze podkreślają zatem otwartość tekstu prawnego na inne czynniki. Ustalenie to wzmacnia linię argumentacyjną na rzecz przedstawiania procesu wykładni jako gry między tekstem prawnym a interpretatorem, w której to grze ważne miejsce pełnią rozstrzygnięcia w zakresie kultury prawniczej i kultury polityczno-prawnej.

\section{Uwagi końcowe}

Zadanie, jakie sobie postawiliśmy w niniejszym artykule, sprowadza się do próby spojrzenia na derywacyjną koncepcję wykładni prawa z perspektywy struktury granic władzy prawniczej. W tym kontekście ważne i zachęcające były dla nas słowa M. Zielińskiego i M. Zirk-Sadowskiego, według których wykładnia jest pewnego rodzaju grą między tekstem a interpretatorem. Koncepcję derywacyjną staraliśmy się odczytywać jako systemowo przygotowaną instrukcję takiej skomplikowanej gry, w której czynniki pozatekstowe z różną intensywnością i na wiele sposobów dopełniają tekst. Dodatkowym bodźcem była dla nas deklarowana otwartość koncepcji derywacyjnej oraz stwierdzona explicite kompatybilność z hermeneutyczną tradycją myślenia o interpretacji.

Tytułem końcowego wynotowania najważniejszych dla nas ustaleń warto zwrócić uwagę na następujące kwestie.

Po pierwsze, w modelu derywacyjnym tekst prawny dostarcza podstawowego odniesienia przy ustalaniu treści prawa, nie determinując jej jednak w całości. Innymi słowy, tekst jest ważnym, ale nie jedynym wyznacznikiem tego, jak interpretator powinien rekonstruować prawo.

93 M. Zieliński, Wyktadnia..., s. 217.

94 J. Leszczyński, Pozytywizacja..., s. 227.

95 Zob. M. Smolak, Uzasadnienie decyzji interpretacyjnej jako praktyczne rozumowanie prawnicze, w: A. Choduń, S. Czepita (red.), W poszukiwaniu..., s. 152.

96 Na temat roli aksjologii otwartej w procesie wykładni prawa: L. Leszczyński, Wykładnia prawa..., s. 60 i n. 
Po drugie, wydaje się, że w omawianej koncepcji wykładni możemy z jednej strony znaleźć znaczny stopień potwierdzenia i uszczegółowienia tego, co zostało wyżej określone jako relacja korekty, z drugiej zaś strony - modyfikację tego, co w strukturze granic funkcjonuje jako relacja dopełniania. Problematyczna staje się mianowicie założona przez nas jednokierunkowość tej relacji. Choć można uznać, że sekwencyjność stosowania reguł wykładni, połączona z pierwszeństwem reguł językowych względem pozajęzykowych częściowo potwierdza zasadniczą prawidłowość takiego kierunku, to bliższe przyjrzenie się modelowi derywacyjnemu nasuwa wniosek, iż mamy tu jednak do czynienia z relacją bardziej złożoną. W szczególności wydaje się, że odwołanie do kultury polityczno-prawnej jest istotne nie tylko przy - dopuszczalnym wyjątkowo - przełamywaniu semantycznego znaczenia tekstu (a więc w kontekście relacji korekty), lecz również przy bardziej standardowym przebiegu ustalania treści prawa, a więc dopełniania semantyki tekstu znaczeniem wynikającym z kontekstu pozajęzykowego, mieszczącego się jednak w granicach wyznaczonych przez tę semantykę (relacja dopełniania). Mówiąc krócej, relacja dopełniania, choć często zachowuje wskazany przez nas kierunek, może także przyjmować inną postać, tj. wzajemnego dopełniania się niektórych przynajmniej granic.

Po trzecie, derywacyjny model wykładni odsłania znaczenie refleksyjności w procesie interpretacji, a więc również rolę, jaką odgrywa w niej postawa przyjęta przez interpretatora. Jakość norm prawnych rekonstruowanych z przepisów zależy więc nie tylko od samych tych przepisów oraz narzędzi i sposobów działania wypracowanych przez kulturę prawniczą, lecz też od postawy poszczególnych uczestników tej kultury, ich refleksyjności, a także związanego z nią wyczucia aksjologicznego.

Na tle powyższych ustaleń pojawiają się kolejne pytania i wątpliwości, które tu jedynie sygnalizujemy. Pierwsze z nich łączy się z drugim ze wskazanych wyżej wniosków. Być może bowiem wskazany tam wyjątek bierze się nie tyle z odwrócenia kierunku dopełniania, ile z przyczyny bardziej jeszcze elementarnej. Otóż w koncepcji derywacyjnej nie tylko nie ma przyjętego przez nas rozszczepienia czynnika kulturowego na kulturę polityczno-prawną i kulturę prawniczą, ale - jako że jest to model o rodowodzie analitycznym - sam czynnik kulturowy jest też inaczej tematyzowany, przy czym podstawową rolę odgrywa w tym kontekście pojęcie racjonalnego prawodawcy. Model derywacyjny skłania więc do postawienia pytania o zasadność przyjętego przez nas rozszczepienia elementu kulturowego na prawniczy i polityczny.

Druga kwestia dotyczy figury refleksyjności, wskazanej w trzecim z wniosków. Być może powinna ona zostać rozciagnięta również na inne poziomy struktury granic. Refleksyjny lub bezrefleksyjny może być bowiem nie tylko prawnik, lecz także - jak staraliśmy się to zasygnalizować - kultura prawnicza ujmowana jako całość oraz faktyczny prawodawca kreujący tekst prawny. W wariancie pozytywnym, gdy udaje się uruchomić refleksję, mamy do czynienia z wzajemnym optymalizowaniem wyników działania poszczególnych granic, a czasem i optymalizowaniem samych tych granic (np. z poprawianiem jakości kultury prawniczej przez indywidualny wkład poszczególnych jurystów). W wariancie negatywnym - dzieje się coś zgoła przeciwnego.

\section{On an Interpreter's Game with the Legal Text and Extratextual Factors in the Derivative Concept of Legal Interpretation}

Abstract: The aim of this paper is to show the derivative concept of legal interpretation from the point of view of the structure of limits of the juridical power. This structure includes the politico-legal culture, the legal text, the juridical culture, and personal factors, such as ethical and aesthetic judgements. 
These days, the derivative concept is the most influential Polish theory of legal interpretation. According to this concept the process of interpreting the law is a kind of a game between the legal text and extratextual factors, which are treated as extratextual limits of juridical power. On the one hand, the legal text does not determine the full meaning of the law, although it has great importance for it. On the other hand, the derivative concept precisely identifies certain others factors that are relevant for the content of law.

Keywords: derivative concept of legal interpretation, limits of juristic power, legal text 


\section{BIBLIOGRAFIA / REFERENCES:}

Bator, A. (2015). O adekwatności założeń derywacyjnej koncepcji wykładni do badań nad interpretacją prawa Unii Europejskiej. Studia Prawa Publicznego 2/10, 11-34.

Bogucki, O. (2016). Model wyktadni funkcjonalnej $w$ derywacyjnej koncepcji wyktadni prawa. Szczecin: Polgres.

Bogucki, O. (2013). O sposobach pojmowania twórczego charakteru interpretacji. Archiwum Filozofii Prawa i Filozofii Spolecznej 1/6, 21-33.

Choduń, A. (2018). Aspekty językowe derywacyjnej koncepcji wyktadni prawa. Szczecin: Wydawnictwo Naukowe Uniwersytetu Szczecińskiego.

Choduń, A., Zieliński, M. (2009). Aspekty granic wykładni prawa. In W. Miemiec (Ed.), Księga Jubileuszowa Profesora Ryszarda Mastalskiego. Stanowienie i stosowanie prawa podatkowego. Wrocław: Oficyna Wydawnicza Unimex.

Czepita, S., Wronkowska, S., Zieliński, M. (2013). Założenia szkoły poznańsko-szczecińskiej w teorii prawa. Państwo i Prawo 2/68, 3-16.

Giddens, A. (2010). Nowoczesność i tożsamość. „Ja” i spoleczeństwo w epoce późnej nowoczesności. Warszawa: Wydawnictwo Naukowe PWN.

Gizbert-Studnicki, T. (2010). Dyrektywy wykładni drugiego stopnia. In A. Choduń, S. Czepita (Eds.), $W$ poszukiwaniu dobra wspólnego. Księga jubileuszowa Profesora Macieja Zielińskiego. Szczecin: Wydawnictwo Naukowe Uniwersytetu Szczecińskiego.

Gizbert-Studnicki, T. (2003). Rozkład ciężaru argumentacji w dyskursie interpretacyjnym. In J. Stelmach (Ed.), Studia z filozofii prawa. Kraków: Wydawnictwo Uniwersytetu Jagiellońskiego.

Gizbert-Studnicki, T. (1985). Wykładnia celowościowa. Studia Prawnicze 85-86, 51-70.

Godek, A. (2011). Czy koniec teorii wykładni prawa? Kilka uwag o możliwych rozwinięciach derywacyjnej koncepcji wykładni Macieja Zielińskiego na wykładnię prawa $\mathrm{w}$ sferze postakcesyjnej z wewnętrznej perspektywy interpretacyjnej. In P. Jabłoński (Ed.), Czy koniec teorii prawa? Z zagadnień teorii i filozofii prawa, numer monograficzny Acta Universitatis Wratislaviensis, No. 3337, seria Prawo, CCCXII. Wrocław: Wydawnictwo Uniwersytetu Wrocławskiego.

Gromski, W. (2011). Autonomia prawa jako funkcja kultury prawnej. In W. Gromski (Ed.), Zzagadnień teorii i filozofii prawa. Autonomia prawa. Wrocław: Kolonia Limited.

Jabłoński, P., Kaczmarek, P. (2017). Granice władzy prawniczej w perspektywie polskiej tradycji socjologicznej. Kraków: Wydawnictwo NOMOS.

Kaczmarek, P. (2019). Dystans do roli w zawodzie prawnika. Warszawa: Wydawnictwo C.H. Beck.

Kaufmann, J.-C. (2013). Kiedy Ja jest innym. Dlaczego i jak coś się w nas zmienia. Warszawa: Oficyna Naukowa.

Kozak, A. (1997). Charakterystyka kategorii „racjonalny prawodawca” w sądowym stosowaniu prawa. In M. Zirk-Sadowski (Ed.), Filozoficzno-teoretyczne problemy sadowego stosowania prawa. XII Ogólnopolski Zjazd Katedr Teorii i Filozofii Prawa (Łódź, 8-10 listopada 1996 r.). Łódź: Wydawnictwo Uniwersytetu Łódzkiego. 
Kozak, A. (1997). Pojmowanie prawa w teorii wykładni. Wrocław: Wydawnictwo Uniwersytetu Wrocławskiego.

Leszczyński, J. (2010). Pozytywizacja prawa $w$ dyskursie dogmatycznym. Kraków: Towarzystwo Autorów i Wydawców Prac Naukowych Universitas.

Leszczyński, L. (2009). Wykładnia operatywna (podstawowe właściwości). Państwo i Prawo 6, 11-23.

Kalisz, A., Leszczyński, L., Liżewski, B. (2011). Wykładnia prawa. Model ogólny a perspektywa Europejskiej Konwencji Praw Człowieka i prawa Unii Europejskiej. Lublin: Wydawnictwo Uniwersytetu Marii Curie-Skłodowskiej.

Leszczyński, L. (2001). Zagadnienia teorii stosowania prawa. Doktryna i tezy orzecznictwa. Kraków: Kantor Wydawniczy Zakamycze.

Matczak, M. (2010). Dwupoziomowość języka prawnego w derywacyjnej koncepcji wykładni i jej znaczenie dla współczesnych sporów w anglosaskiej interpretacji prawniczej. In A. Choduń, S. Czepita (Eds.), W poszukiwaniu dobra wspólnego. Księga jubileuszowa Profesora Macieja Zielińskiego. Szczecin: Wydawnictwo Naukowe Uniwersytetu Szczecińskiego.

Matczak, M. (2019). Imperium tekstu. Prawo jako postulowanie i urzeczywistnianie świata możliwego. Warszawa: Wydawnictwo Scholar.

Nowak, L. (1999). Zygmunta Ziembińskiego koncepcja interpretacji. Pewne komentarze, dopełnienia i aplikacje. In A. Klawitera, L. Nowak, P. Przybysz (Eds.), Umysł a rzeczywistość. Poznań: Zysk i s-ka.

Pichlak, M. (2019). Refleksyjność prawa. Od teorii spotecznej do strategii regulacji i z powrotem. Łódź: Wydawnictwo Uniwersytetu Łódzkiego.

Pietrzykowski, T. (2017). Naturalizm i granice nauk prawnych. Esej z metodologii prawoznawstwa. Warszawa: Wolters Kluwer.

Płeszka, K., Gizbert-Studnicki, T. (1984). Dwa ujęcia wykładni prawa. Próba konfrontacji. Zeszyty Naukowe Uniwersytetu Jagiellońskiego, Prace z nauk politycznych 20, 17-27.

Płeszka, K. (2010). Wyktadnia rozszerzająca. Kraków: Wolters Kluwer Polska.

Podgórecki, A. (2016). Mega-sociology. Warszawa: Instytut Profilaktyki Społecznej i Resocjalizacji UW.

Safjan, M. (2010). Uniwersalizacja wykładni prawa. In A. Choduń, S. Czepita (Eds.), W poszukiwaniu dobra wspólnego. Księga jubileuszowa Profesora Macieja Zielińskiego. Szczecin: Wydawnictwo Naukowe Uniwersytetu Szczecińskiego.

Sarkowicz, R. (2005). Uwagi o współczesnej interpretacji prawniczej. In S. Wronkowska (Ed.), Polska kultura prawna a proces integracji europejskiej. Kraków: Kantor Wydawniczy Zakamycze.

Smolak, M. (2010). Uzasadnienie decyzji interpretacyjnej jako praktyczne rozumowanie prawnicze. In A. Choduń, S. Czepita (Eds.), W poszukiwaniu dobra wspólnego. Księga jubileuszowa Profesora Macieja Zielińskiego. Szczecin: Wydawnictwo Naukowe Uniwersytetu Szczecińskiego.

Smolak, M. (2012). Wyktadnia celowościowa z perspektywy pragmatycznej. Warszawa: Wolters Kluwer Polska.

Spyra, T. (2006). Granice wyktadni prawa. Znaczenie językowe tekstu prawnego jako granica wyktadni. Kraków: Kantor Wydawniczy Zakamycze. 
Walasik, M. (2013). Analogia w prawie procesowym cywilnym. Warszawa: LexisNexis.

Zieliński, M., Bogucki, O., Choduń, A., Czepita, S., Kanarek, B., Municzewski, A. (2009). Zintegrowanie polskich koncepcji wykładni prawa. Ruch Prawniczy, Ekonomiczny $i$ Socjologiczny 2009/4, 23-39.

Zieliński, M. (2012). Clara non sunt interpretanda - mity i rzeczywistość. Zeszyty Naukowe Sadownictwa Administracyjnego 2012/6, 9-23.

Zieliński, M. (2006). Derywacyjna koncepcja wykładni jako koncepcja zintegrowana. Ruch Prawniczy, Ekonomiczny i Socjologiczny 2006/3, 93-101.

Zieliński, M. (1972). Interpretacja jako proces dekodowania tekstu prawnego. Poznań: Wydawnictwo Naukowe Uniwersytetu im. Adama Mickiewicza w Poznaniu.

Zieliński, M. (2011). Mitów w myśleniu o wykładni prawa ciąg dalszy. In A. Mróz, A. Niewiadomski, M. Pawelec (Eds.), Prawo - język - media. Warszawa: Międzywydziałowe Koło Naukowe Kultury Języka Prawnego i Prawniczego Lingua Iuris.

Zieliński, M. (2005). Podstawowe zasady współczesnej wykładni prawa. In P. Winczorek (Ed.), Teoria i praktyka wyktadni prawa. Warszawa: Wydawnictwo Liber.

Zieliński, M. (2017). Wykładnia prawa. Zasady - reguly-wskazówki. Warszawa: Wolters Kluwer Polska.

Zieliński, M. (1998). Wyznaczniki reguł wykładni prawa. Ruch Prawniczy Ekonomiczny i Socjologiczny 3-4/LX, 1-20.

Zieliński, M., Zirk-Sadowski, M. (2011). Klaryfikacyjność i derywacyjność w integrowaniu polskich teorii wykładni prawa. Ruch Prawniczy, Ekonomiczny i Socjologiczny 2/LXXIII, 99-111.

Ziembiński, Z. (1980). Problemy podstawowe prawoznawstwa. Warszawa: Państwowe Wydawnictwo Naukowe.

Ziembiński, Z. (1960). Przepis prawny i norma prawna. Ruch Prawniczy Ekonomiczny i Socjologiczny, $1 / 22,105-122$.

Ziembiński, Z. (1990). Wstęp do aksjologii dla prawników. Warszawa: Wydawnictwo Prawnicze.

Ziembiński, Z. (1993). Tworzenie a stanowienie i stosowanie prawa. Ruch Prawniczy, Ekonomiczny i Socjologiczny 4, 43-50.

Zirk-Sadowski, M. (2001). Pozytywizm prawniczy a filozoficzna opozycja podmiotu i przedmiotu poznania. In J. Stelmach (Ed.), Studia z filozofii prawa. Kraków: Wydawnictwo Uniwersytetu Jagiellońskiego. 